\title{
Meteorological Annual Report for 1994 (U)
}

by

c. H. Hunter

Westinghouse Savannah River Company

Savannah River Site

Aiken, South Carolina 29808

$L$ M. Loard

DOE Contract No. DE-AC09-89SR18035

This paper was prepared in connection with work done under the above contract number with the U. S.

Department of Energy. By acceptance of this paper, the publisher and/or recipient acknowledges the U. S.

Government's right to retain a nonexclusive, royalty-free license in and to any copyright covering this paper, along with the right to reproduce and to authorize others to reproduce all or part of the copyrighted paper. 


\section{Meteorological Annual Report for 1994}
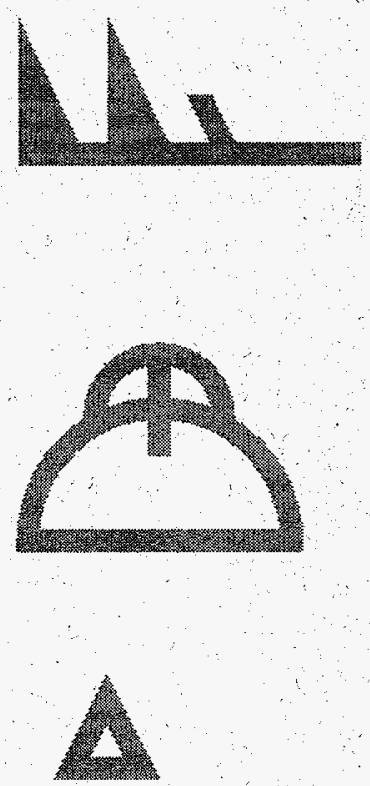

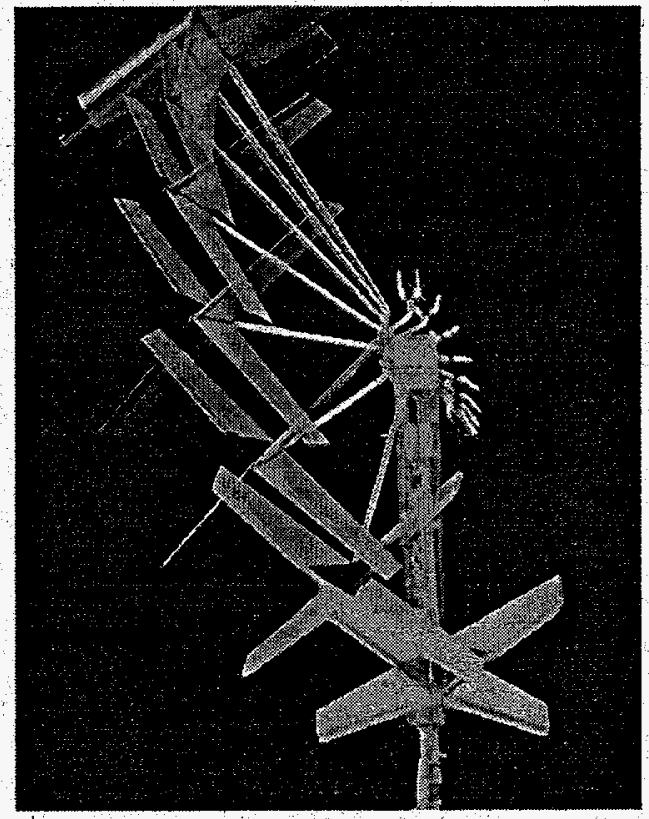

at the Savannah River Site

Savannah River Technology Center
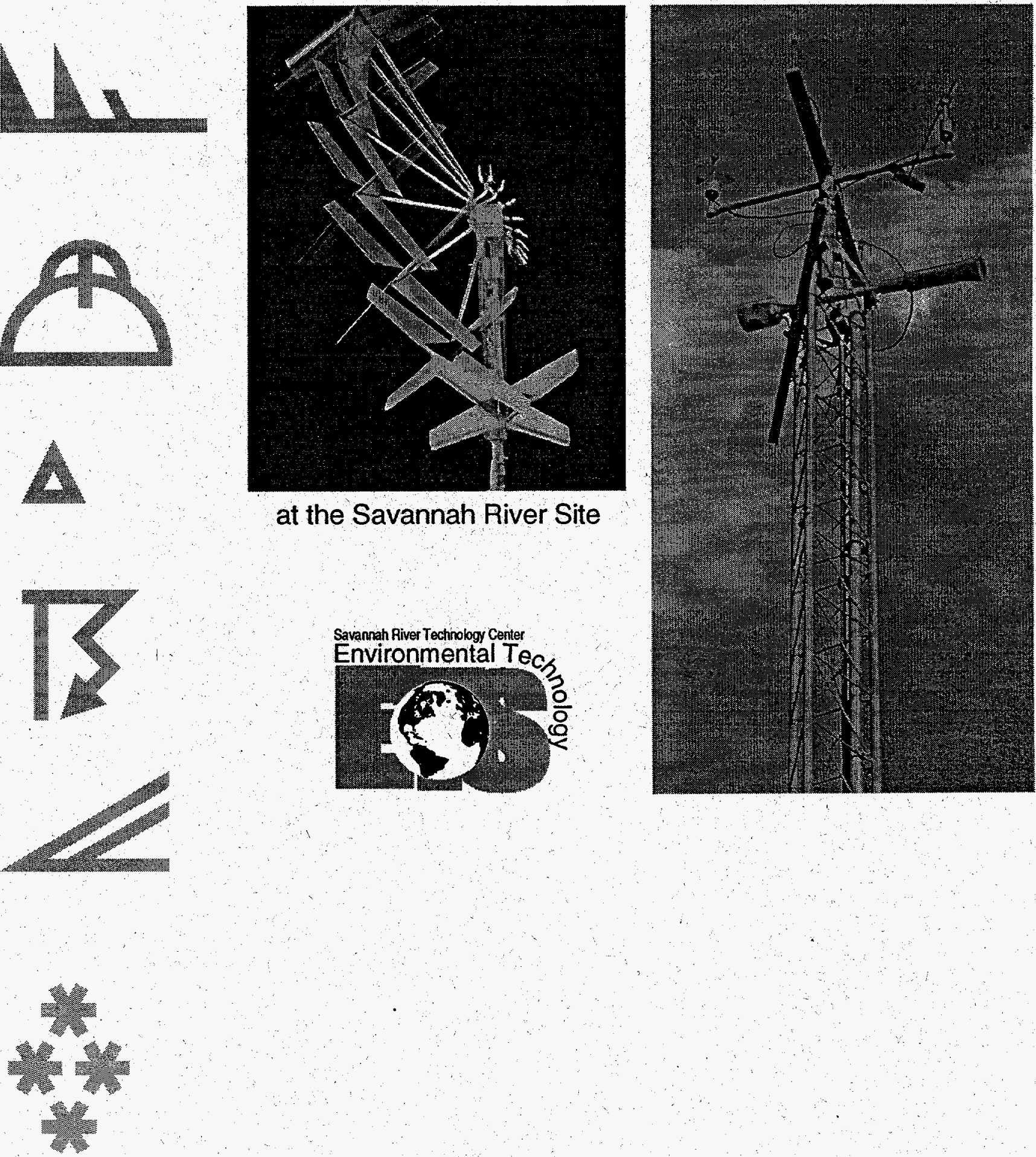


\section{Disclaimer}

This report was prepared as an account of work sponsored by an agency of the United States Government. Neither the United States Government nor any agency thereof, nor any of their employees, makes any warranty, express or implied, or assumes any legal liability or responsibility for the accuracy, completeness, or usefulness of any information, apparatus, product, or process disclosed, or represents that its use would not infringe privately owned rights. Reference herein to any specific commercial product, process, or service by trade name, trademark, manufacturer, or otherwise does not necessarily constitute or imply its endorsement, recommendation, or favoring by the United States Government or any agency thereof. The views and opinions of authors expressed herein do not necessarily state or reflect those of the United States Government or any agency thereof. 
WSRC-TR-95-0382

Rev 0

September 1995

\section{Meteorological Annual Report for $1994^{(U)}$}

C. H. Hunter

L. M. Leard, visiting teacher with ORISE/BEST Program

Prepared for the U.S. Department of Energy under contract no. DE-AC09-89SR18035 


\title{
Contents
}

\section{Executive Summary 1}

\author{
Introduction 3
}

\section{Data Summaries 5 \\ Temperature 5 \\ Precipitation 5 \\ Relative Humidity 5 \\ Winds 5 \\ Barometric Pressure 6 \\ References 6}

\section{List of Figures}

Figure 1. Daily averages for temperature minimum and maximum, pressure, relative humidity, and precipitation for 19942

Figure 2. 1994 SRTC daily high and low temperatures 7

Figure 3. SRTC annual average temperature 1964-1994 8

Figure 4. SRTC monthly average temperature 9

Figure 5. SRTC number of freezing and sweltering days 10

Figure 6. 1994 SRTC daily precipitation 11

Figure 7. SRTC annual precipitation 1964-1994 12

Figure 8. SRTC monthly precipitation 13

Figure 9. 1994 SRTC daily low humidity 14

Figure 10. SRTC monthly average low relative humidity 15

Figure 11. 1994 SRTC daily high and low humidity 16

Figure 12. Annual wind rose 17

Figure 13. Seasonal wind rose 199418

Figure 14. Seasonal wind rose 1987-91 19 
Figure 15. 1994 daily average barometric pressure 20

Attachment A. Map of the Savannah River Site showing the location for the meteorologocial towers 21 


\section{Executive Summary}

An analysis of basic meteorological data collected at the Savannah River Site (SRS) shows that the year 1994 was slightly warmer and drier than average. In most months, average minimum and maximum temperatures were near or slightly above the average for the 31-year period of 1964 through 1991. Above-average warmth was particularly evident in November and December. January of 1994 was a relatively cold month because of a major influx of Arctic air during the middle of the month. Observed temperatures for the year ranged from $10^{\circ} \mathrm{F}$ in January to $98^{\circ} \mathrm{F}$ in June and August. Although total annual precipitation was slightly below average, monthly total precipitation for October was the second highest since 1964. Observed wind direction for 1994 was generally consistent with long-term patterns. Persistent high pressure to the north of the area during the autumn months resulted in above average frequencies of northeasterly winds.

Annual and seasonal wind speeds in 1994 were slightly above average. Observed daily minimum/maximum temperature, total precipitation, minimum relative humidity, and average barometric pressure are summarized in Figure 1. 

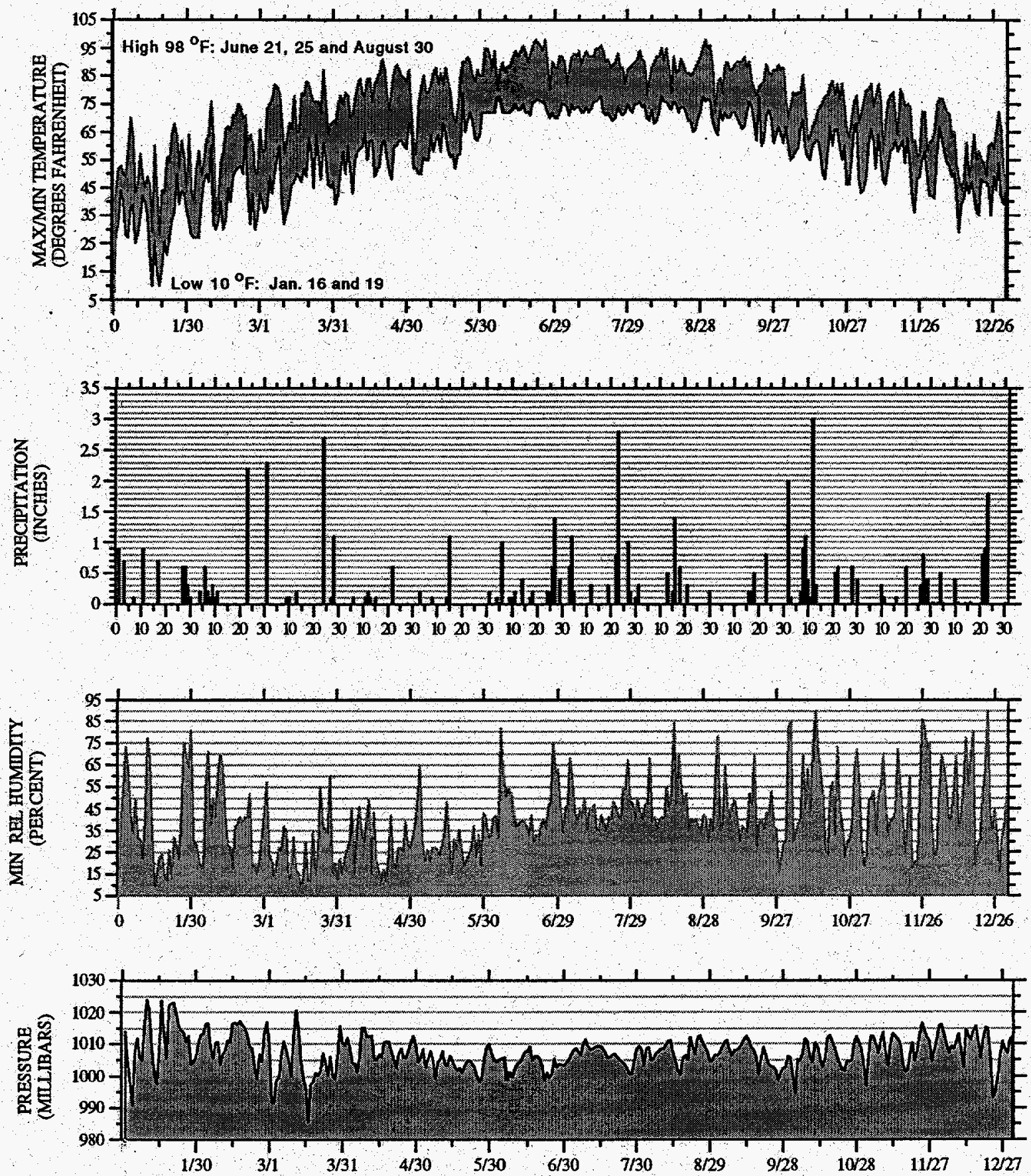

Figure 1. Daily averages for temperature minimum and maximum, pressure, relative humidity, and precipitation for 1994 


\section{Introduction}

The Environmental Technology Section (ETS) of the Savannah River Technology Center (SRTC) collects and archives basic meteorological data that supports a variety of SRS activities including design, construction and operation of nuclear and non-nuclear facilities, environmental compliance, resource management, and research. This report provides summaries of data collected during 1994 for temperature, precipitation, relative humidity, wind, and barometric pressure. Summaries include plots of daily or seasonal data and, where possible, graphical comparisons of the 1994 data to climatology.

Temperature, precipitation, and relative humidity data that are presented in this report were recorded at the 773-A (SRTC) weather station. Temperature and relative humidity are measured by a hygrothermograph mounted in a standard National Weather Service "cotton region" instrument shelter. Data from the hygrothermograph are continuously output to a strip chart recorder. Daily maximum and minimum values of temperature and relative humidity are manually extracted from the strip charts and entered into a computer database. Daily precipitation is measured with a plastic wedge rain gauge located adjacent to the instrument shelter. Rainfall measurements are taken once per day, usually around $9 \mathrm{am}$.

Wind data were collected at the H-Area meteorological tower, one of nine towers at SRS operated by ETS. The H-Area tower data were selected because of the proximity of this location to the geographic center of SRS. The wind measurements are taken at a height of 200 feet above ground. Barometric pressure data were recorded at the ETS Climatology Site tower near Central Shops. A map showing each of the measurement locations is given in Attachment A. Reference 1 and 2 provide complete descriptions of the ETS meteorological monitoring facilities and instrumentation. Additional climatological descriptions of SRS can be found in References 3 and 5. 


\section{Data Summaries}

\section{Temperature}

Temperatures for 1994 ranged from $10^{\circ} \mathrm{F}$, observed on the mornings of January 16 and 19 , to $98^{\circ} \mathrm{F}$ observed on the afternoons of June 21 and 25 and August 30 (Figure 2). The average temperature for 1994 was $67^{\circ} \mathrm{F}$, which is about 2 degrees above the average for the 31-year period of 1964 through 1994 (Figure 3). (The annual average temperatures in Figure 3 should be considered approximate as they are based on averages of observed daily minima and maxima.) June was the warmest month of the year with an average daily maximum of $91^{\circ} \mathrm{F}$ and an average daily minimum of $73^{\circ} \mathrm{F}$; January was the coldest month with an average daily high of $52^{\circ} \mathrm{F}$ and an average daily low of $31^{\circ} \mathrm{F}$ (Figure 4). Monthly averages for 1994 were near or slightly above average in all months except January, which was about $4^{\circ} \mathrm{F}$ below the 31 -year average. The relatively cold average temperatures for January were because of an outbreak of Arctic air over the eastern United States during the middle of the month (Reference 6). Daily high temperatures were greater than $90^{\circ} \mathrm{F}$ on 20 days during the months of June and July. Minimum temperatures were below $32^{\circ}$ on 15 days in January (Figure 5). The number of "freeźe days" in November and December were much below average.

\section{Precipitation}

Rainfall was observed on 87 days during the year (Figure 6). Daily amounts greater than 2 inches were observed on 5 days. Total precipitation for 1994 was 47.16 inches; average annual precipitation for the 31 -year period of 1964 through 1994 was 49.73 inches (Figure 7). Relatively dry periods were observed in April-May and August-September. Relatively rainy periods occurred in March, July, and October. October's monthly total of 10.01 inches was the second wettest October since 1964 (Figure 8).

\section{Relative Humidity}

Relative humidity is defined as the ratio of the vapor pressure of ambient air to its saturation vapor pressure. As the ambient temperature cools to the dew point temperature (assuming constant pressure), morning values of relative humidity can often approach $100 \%$, even when the moisture content of the atmosphere is relatively low. Therefore, observations of aftemoon minimum relative humidity provide a more meaningful indicator of prevailing atmospheric moisture than maximum values.

Lowest values of daily minimum relative humidity were observed in March and April, averaging $26 \%$ and $27 \%$, respectively (Figure 9). Highest daily minimums occurred in October through December. Minimum values greater than $40 \%$ were consistently observed during the summer (Figure 10). The greatest daily variations in relative humidity were observed during January through May and October through December. These variations reflect a progression of weather systems through the area that produce alternating periods of relatively moist subtropical air from the Atlantic or Gulf of Mexico and drier continental air. Atmospheric moisture exhibits much less variability during the summer, as area weather patterns are dominated by relatively moist subtropical air associated with the semipermanent "Bermuda high". A plot of the complete record of daily minimum and maximum relative humidity is shown in Figure 11. Instrument limitations prohibit reliable measurement of relative humidity above $90 \%$.

\section{Winds}

Wind direction observations for 1994 show a slightly higher occurrence of northeasterly and southwesterly winds than were observed during the 5-year period of 1987 through 1991 (Figure 12). Although autumn typically exhibits a relatively high frequency of northeast winds, 1994 was quite unusual as northeast winds were observed more than $20 \%$ of the time (Figures 13 and 14). The frequent occurrence of northeast winds during this period was the result of a series of strong, persistent high pressure areas over the northeast United States in September and October (Reference 6). The summer was characterized by a relatively high occurrence of southwesterly winds from a fairly persistent position of the sub-tropical "Bermuda" high pressure off of the southeast U.S. coast. Strong high-pressure areas associated with the Arctic outbreaks in January resulted in a somewhat higher occurrence of westerly winds for the winter period (Reference 6). Wind direction patterns for spring of 1994 were fairly typical. Annual and seasonal wind speeds for 1994 were slightly greater than the $1987-91$ averages. 


\section{Barometric Pressure}

Average barometric pressure for 1994 was 1006 millibars (mb). The lowest daily average value, $985 \mathrm{mb}$, occurred on March 16; the highest daily average value, $1024 \mathrm{mb}$, occurred January 10 (Figure 15). Relatively high variability in daily average pressure was observed in the months of January through March, associated with the progression of relatively strong weather systems through the area. A long-term record of atmospheric pressure for SRS is not readily available.

\section{References}

1. Parker, M. J., and R. P. Addis, SRS Meteorological Monitoring Program, WSRC-TR-93-0106, Westinghouse Savannah River Company (1994).

2. Kurzeja, R. J., The Savannah River Technology Center Research and Development Climatology Center, WSRC-TR-93-596 (1993).

3. Hunter, C. H., A Climatological Description of the Savannah River Site, WSRC-RP-89-313, Westinghouse Savannah River Company (1990).

4. Hoel, D. D, Climatology of the Savannah River Plant Site, DPST-83-705, E. I. du Pont de Nemours and Company (1994).

5. Weber, A. H., Comparison of Savannah River Site Meteorological Data Bases, WSRC-RP-93-269 (1993).

6. National Atmospheric and Atmospheric Administration, Daily Weather Maps for 1994, Climate Analysis Center, Washington, D.C. 


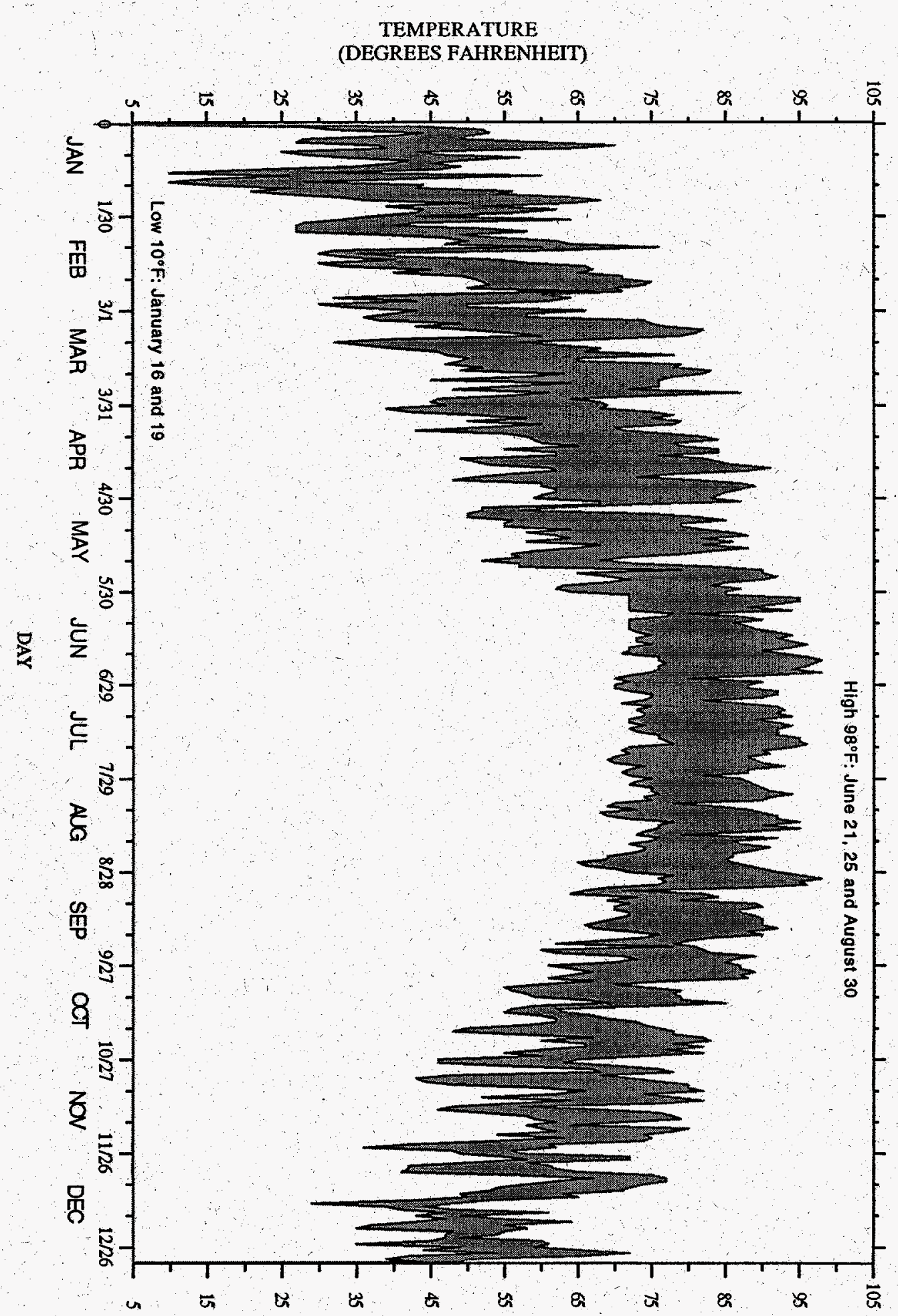

(n) 7661 lof yoday jenuuv jeว!80josozəow 


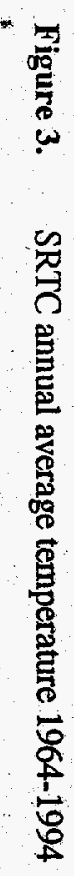

TEMPERATURE

(DEGREES FAHRENHEIT)

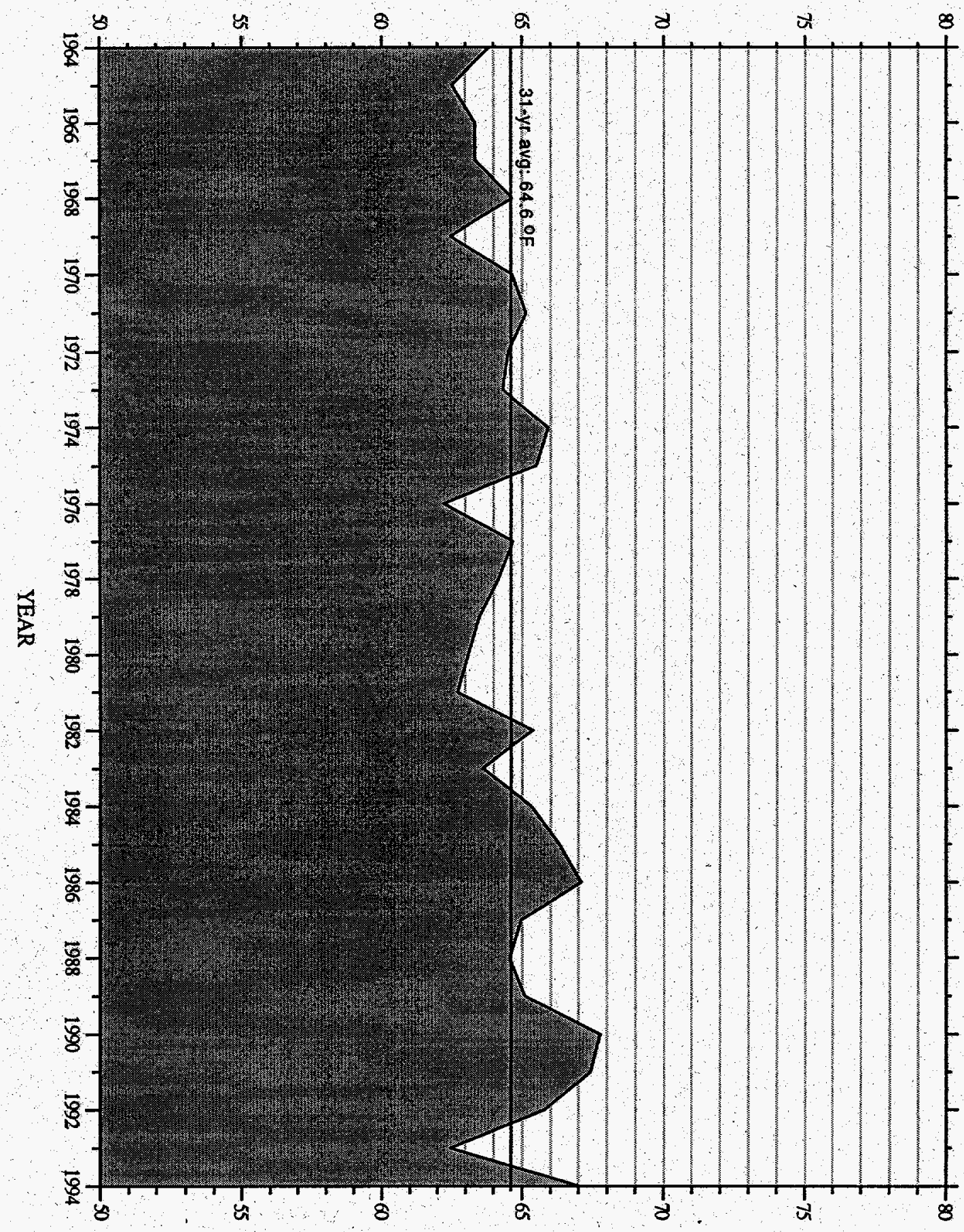




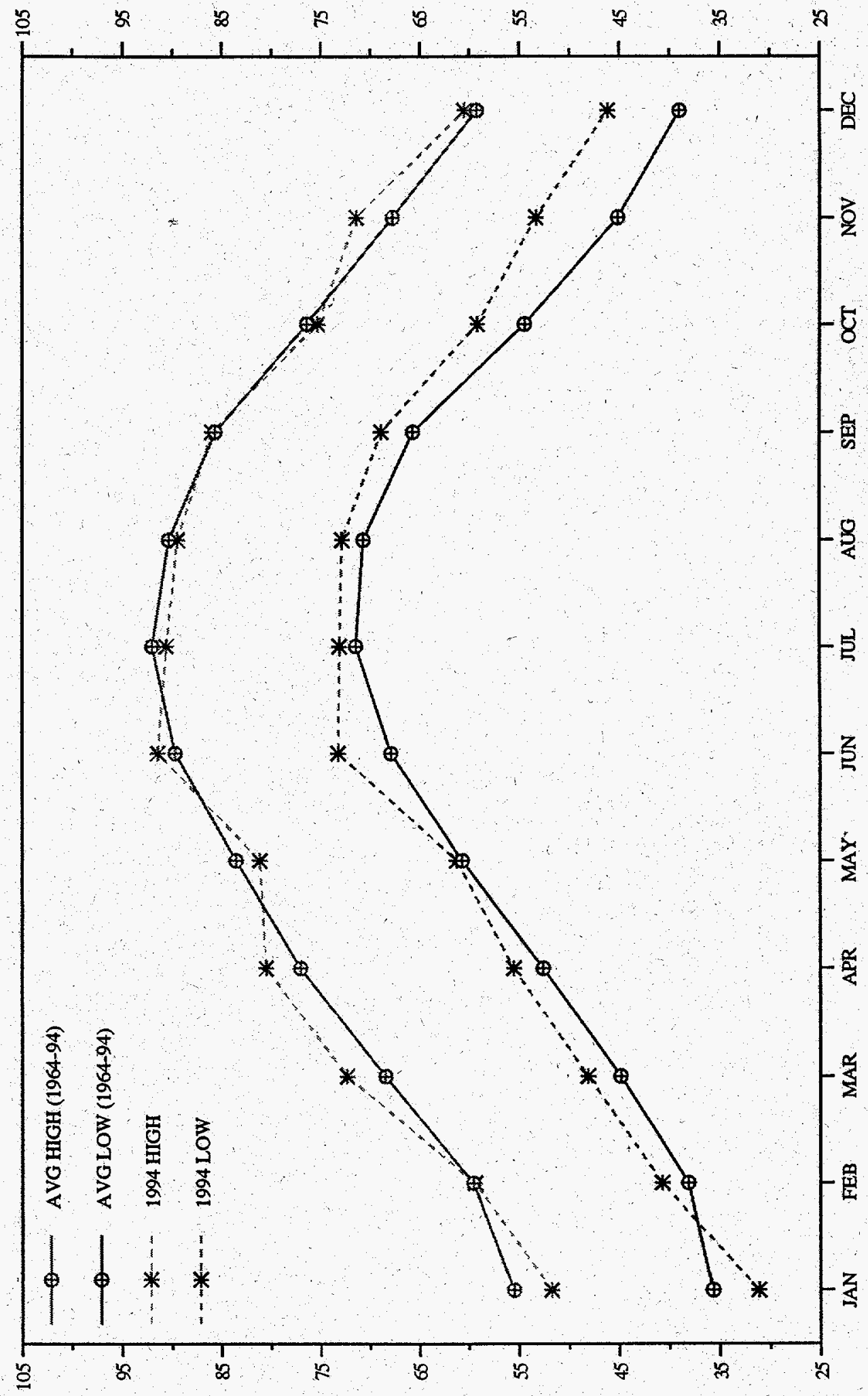

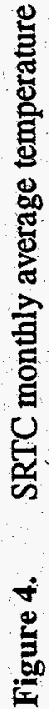




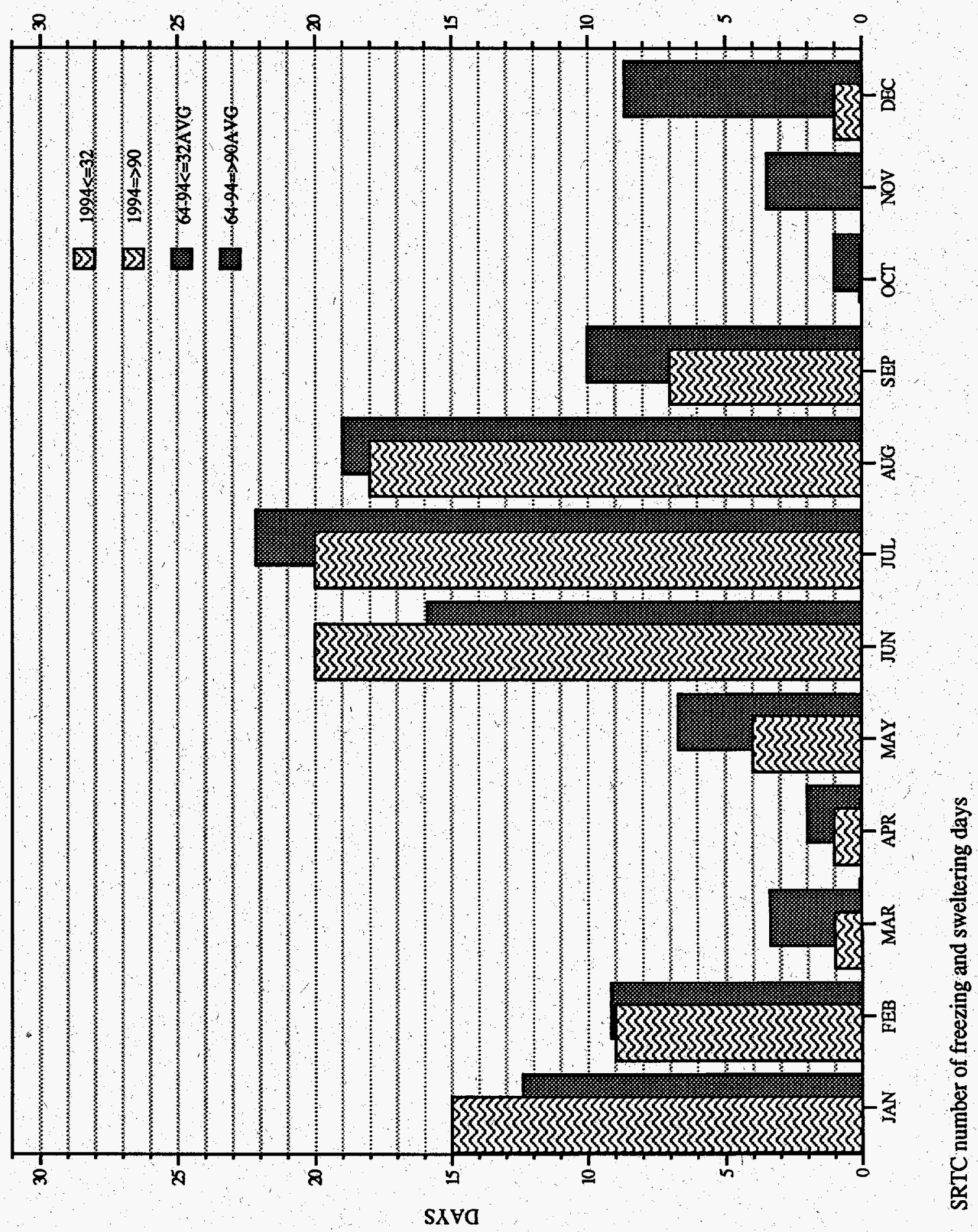

定 


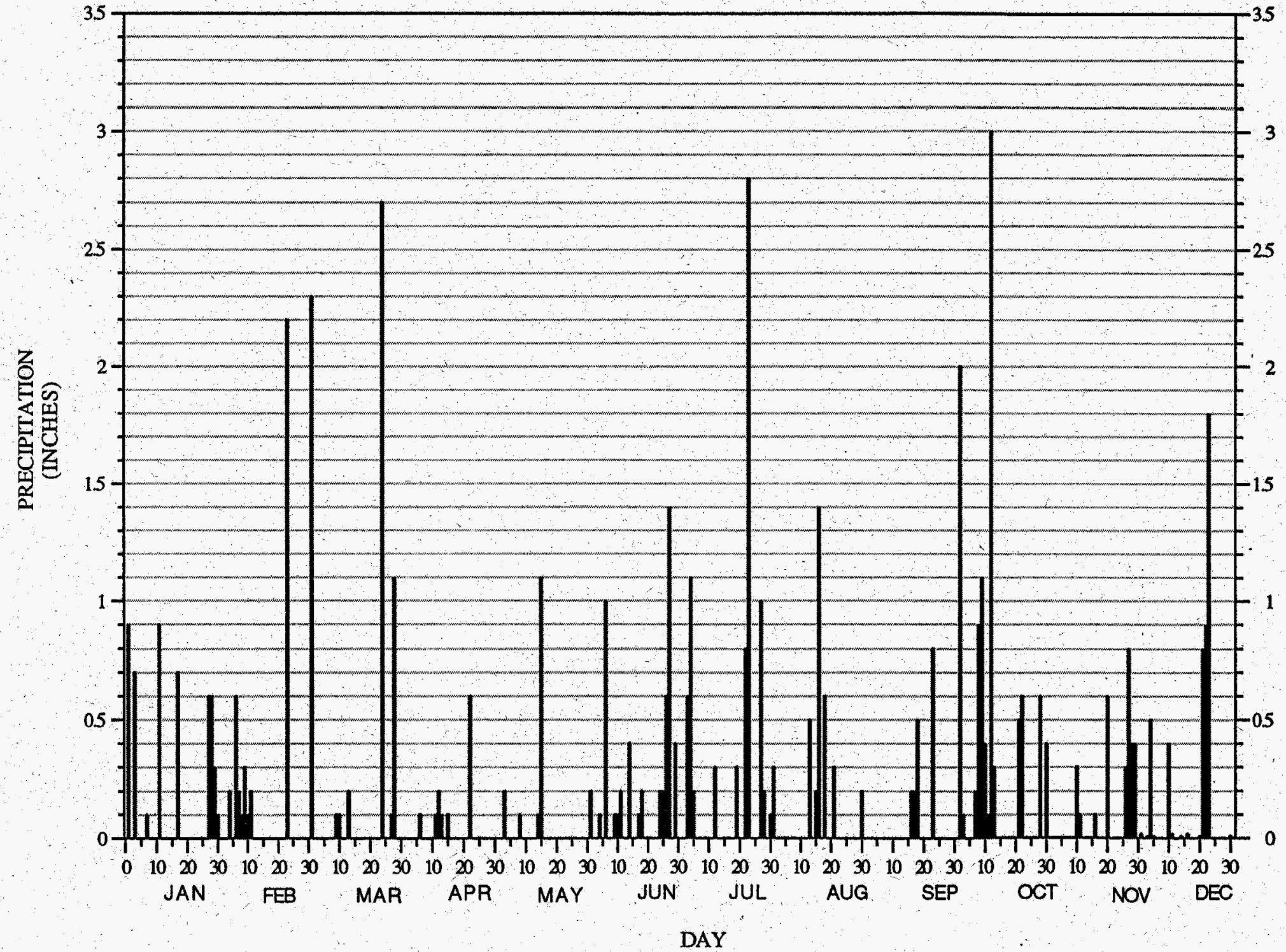




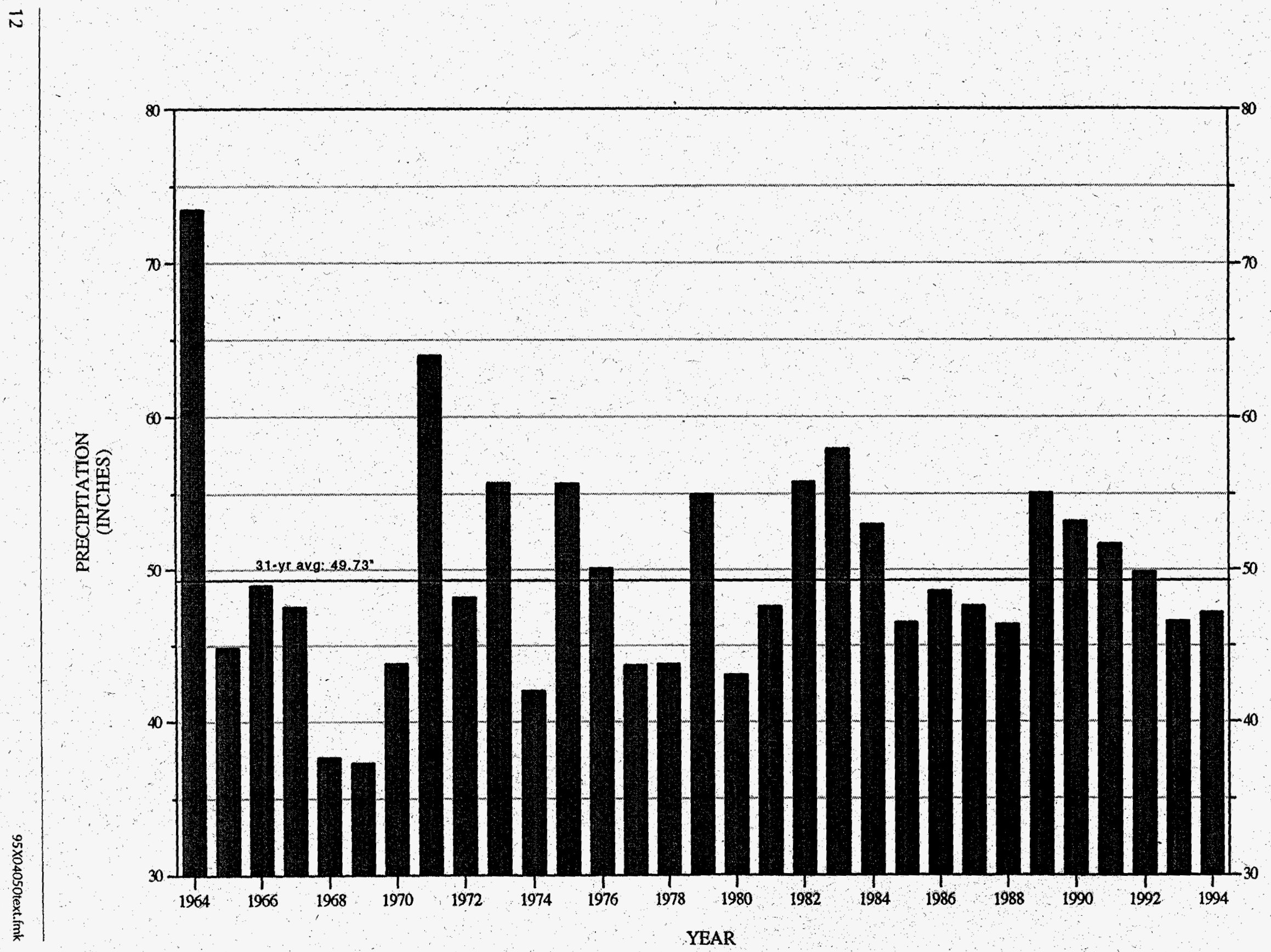

Figure 7. SRTC annual precipitation 1964-1994 

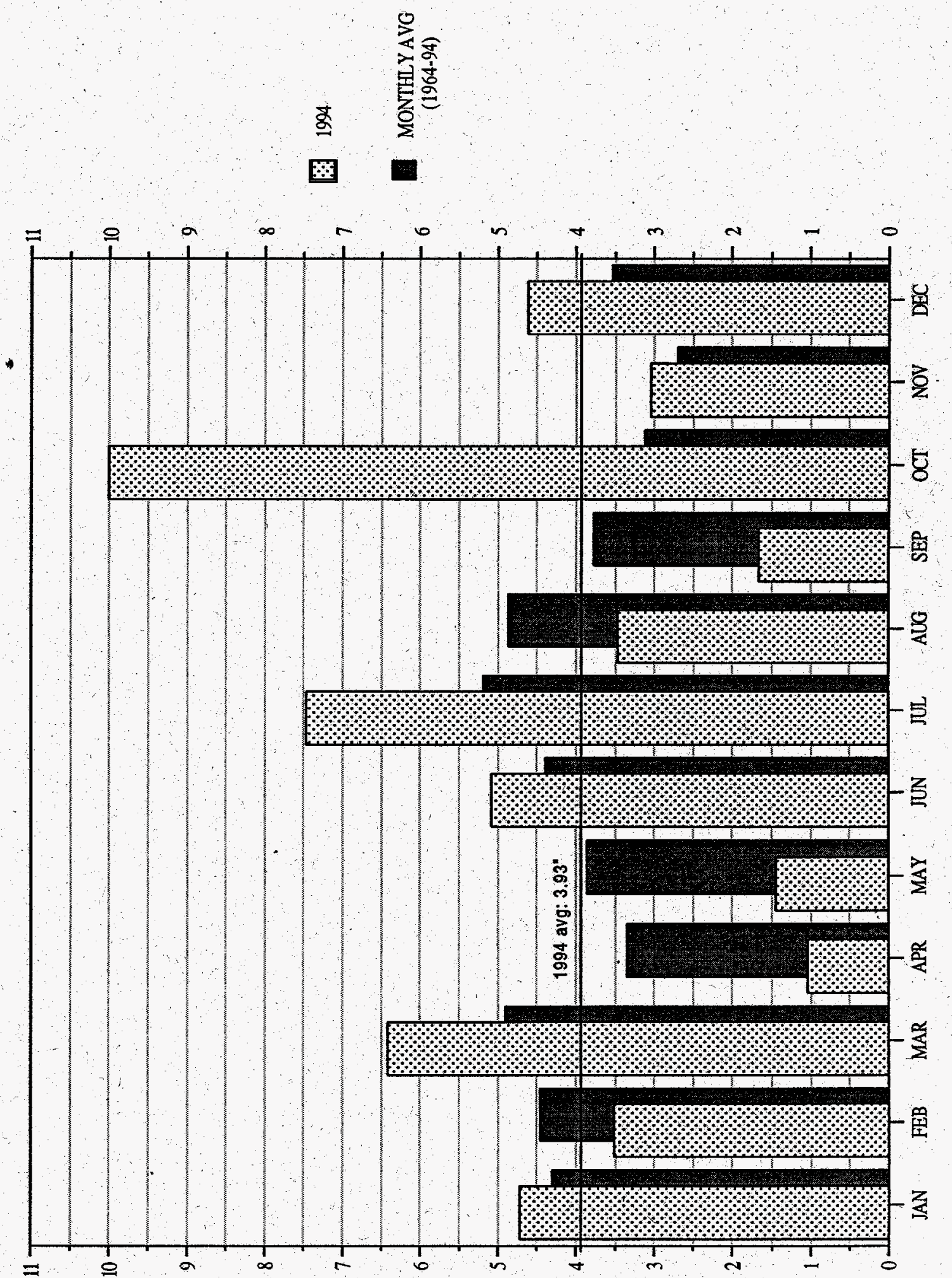

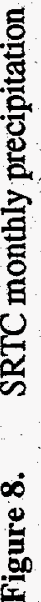




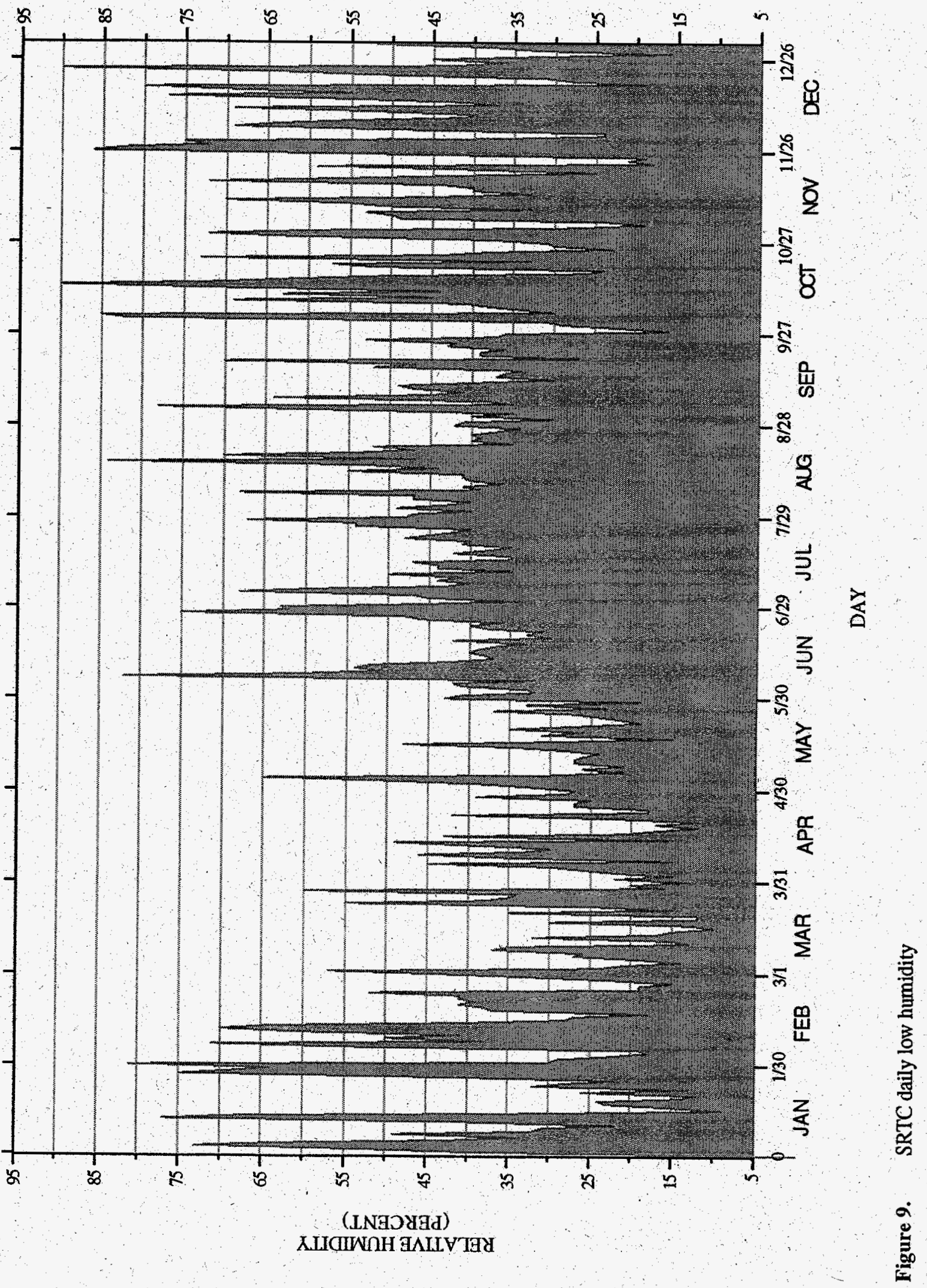




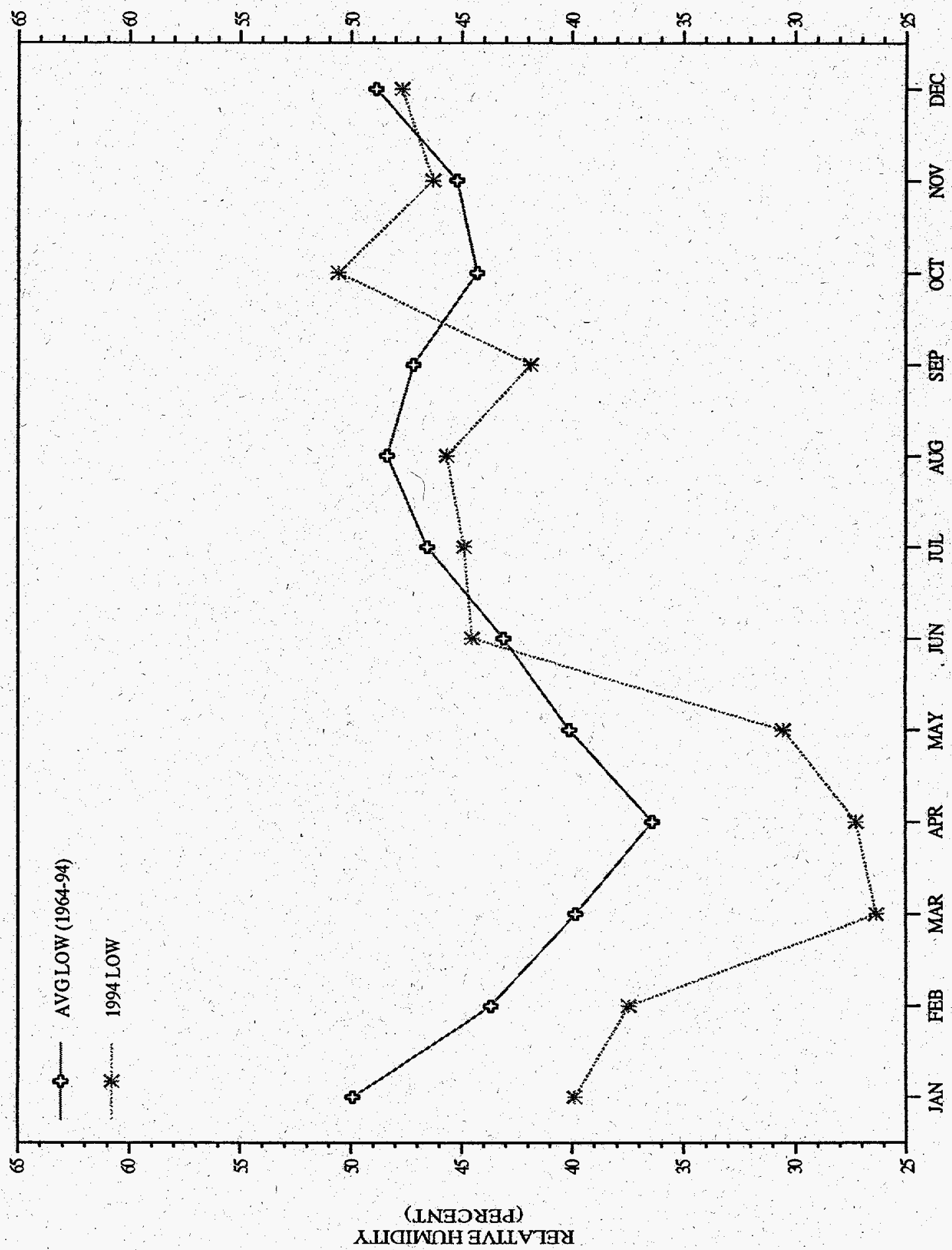

总 


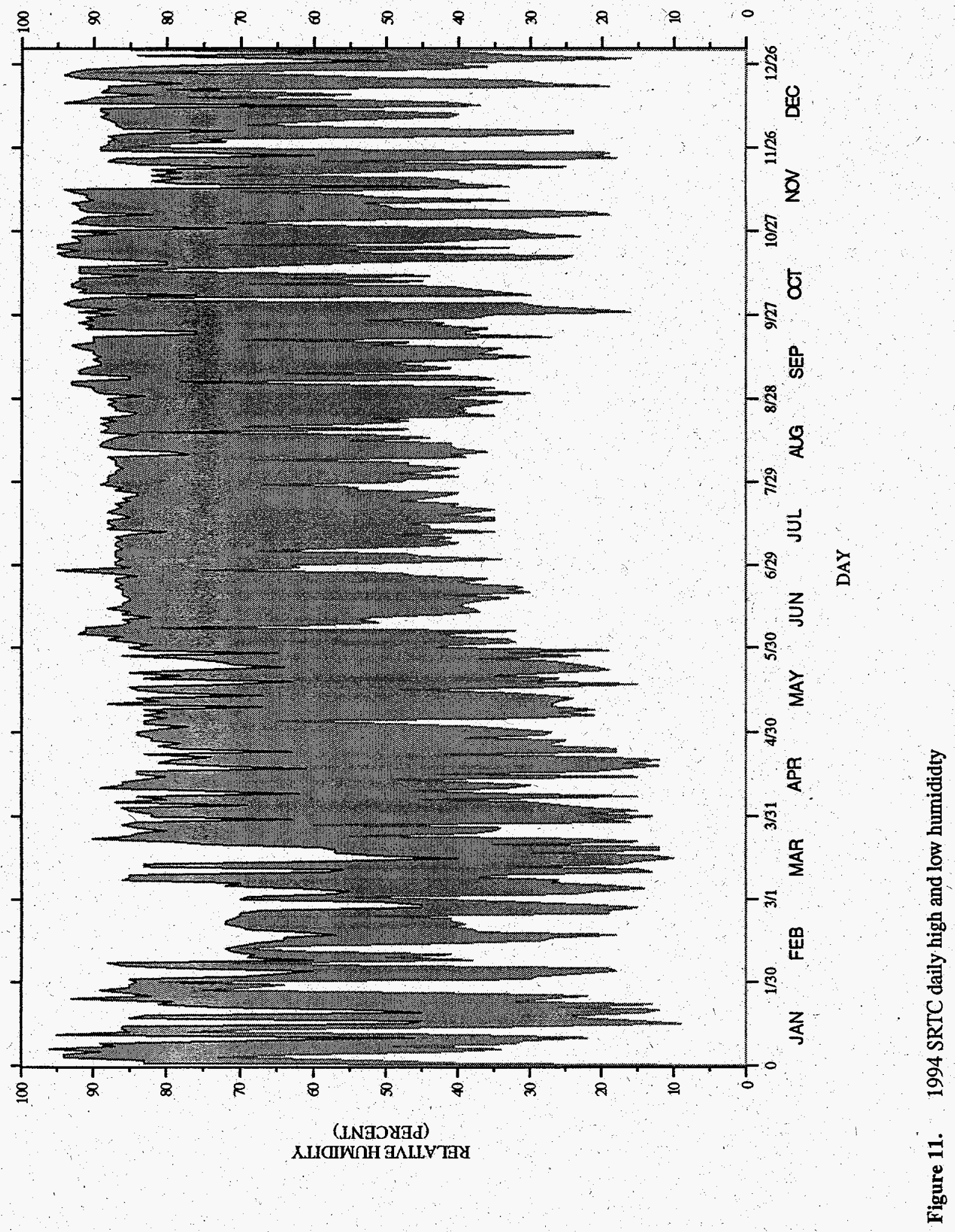



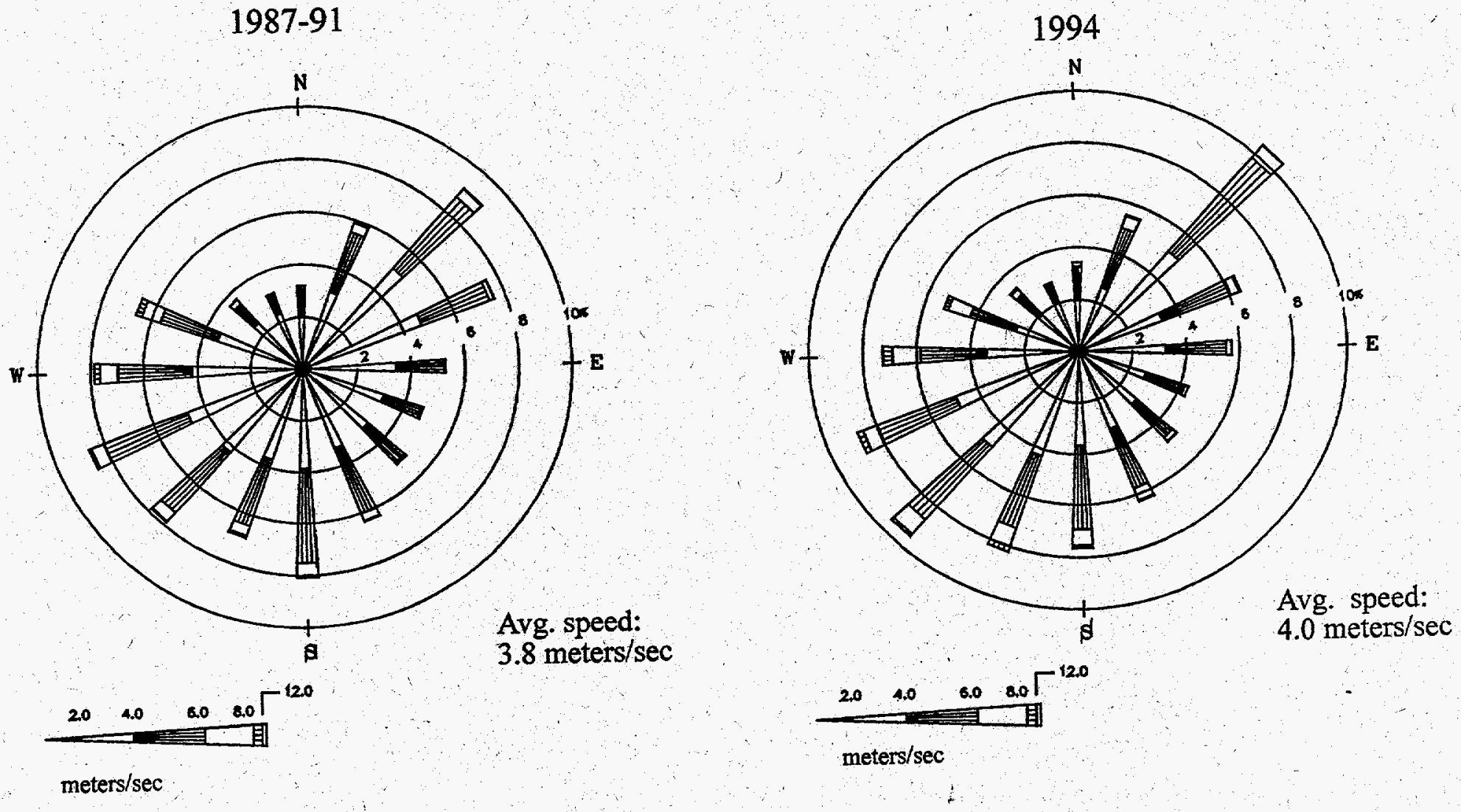

Figure 12. Annual wind rose (Note-Directions are compass sectors from which the wind is blowing.) 

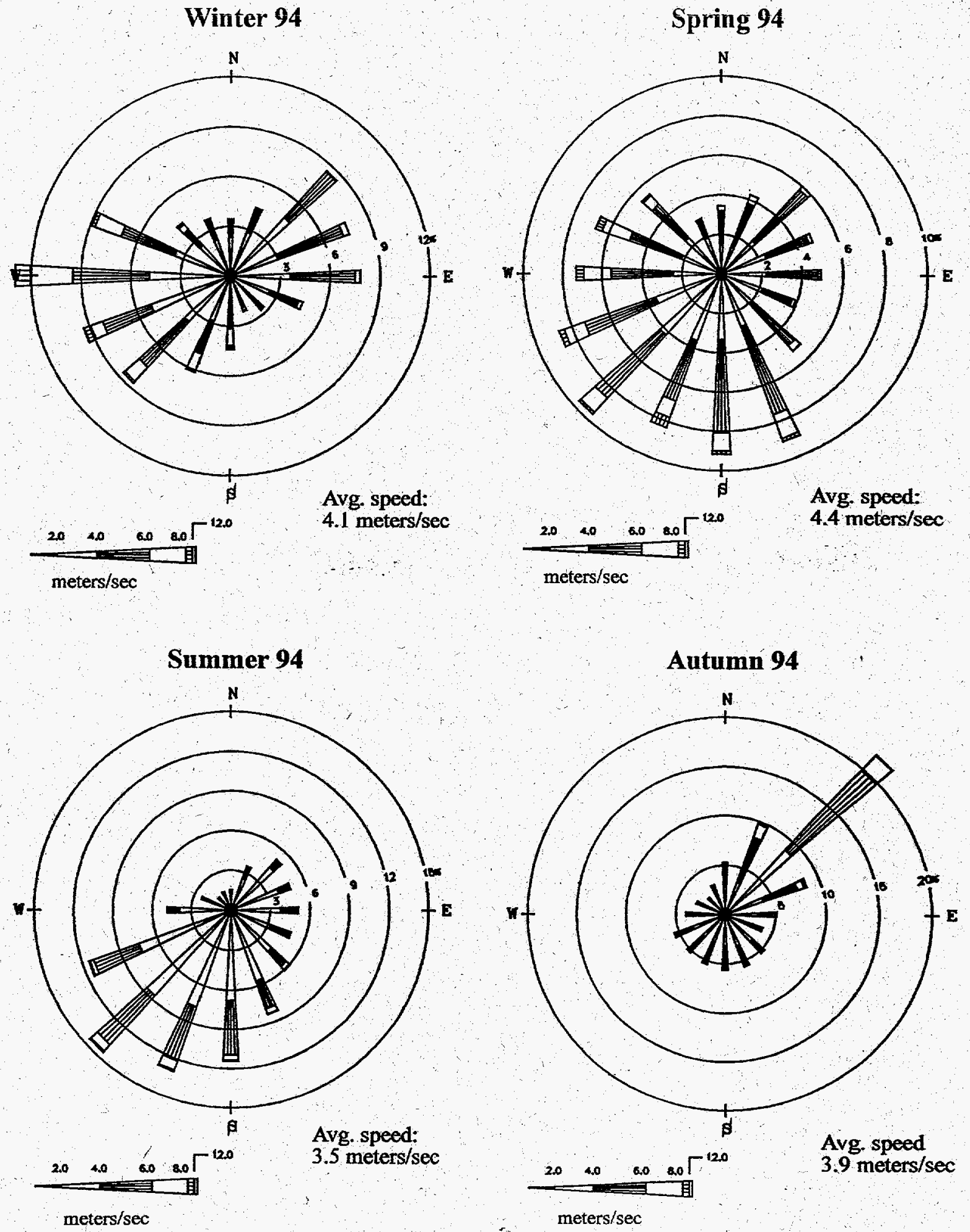

Figure 13. Seasonal wind rose 1994 (Note-Directions are compass sectors from which the wind is blowing.) 

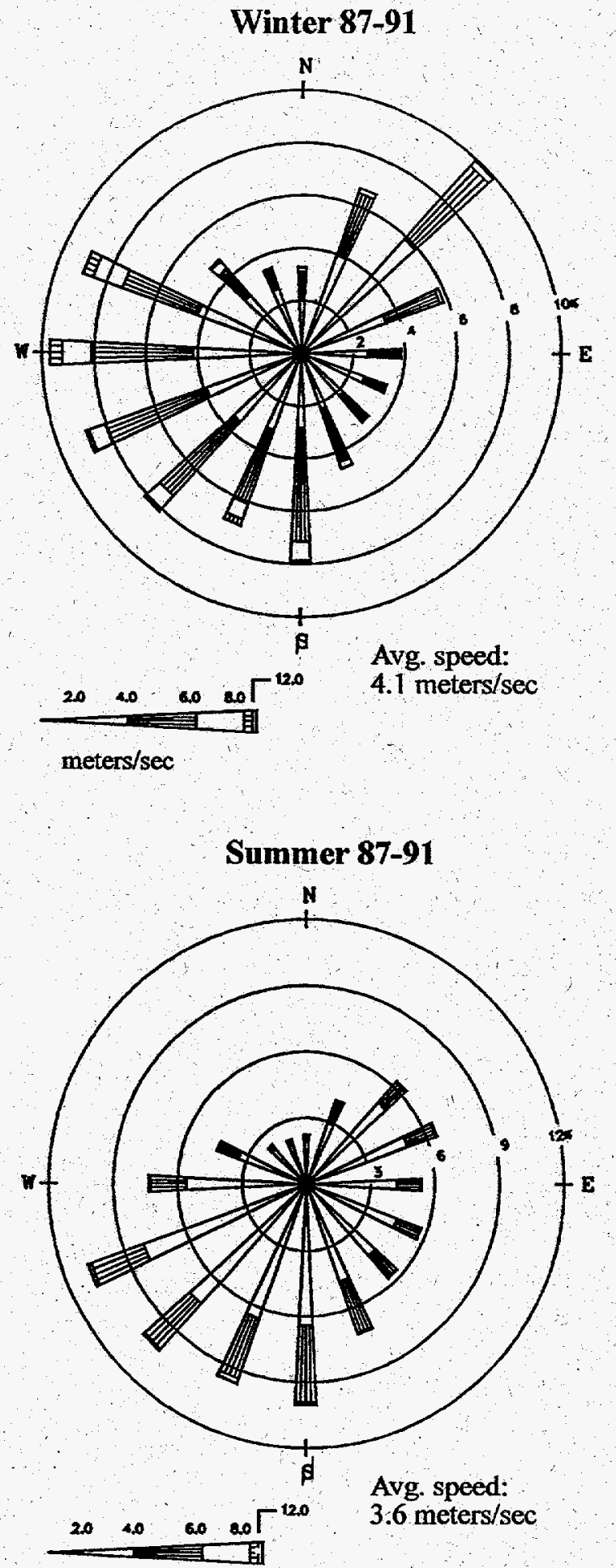

meters/sec
Spring 87-91

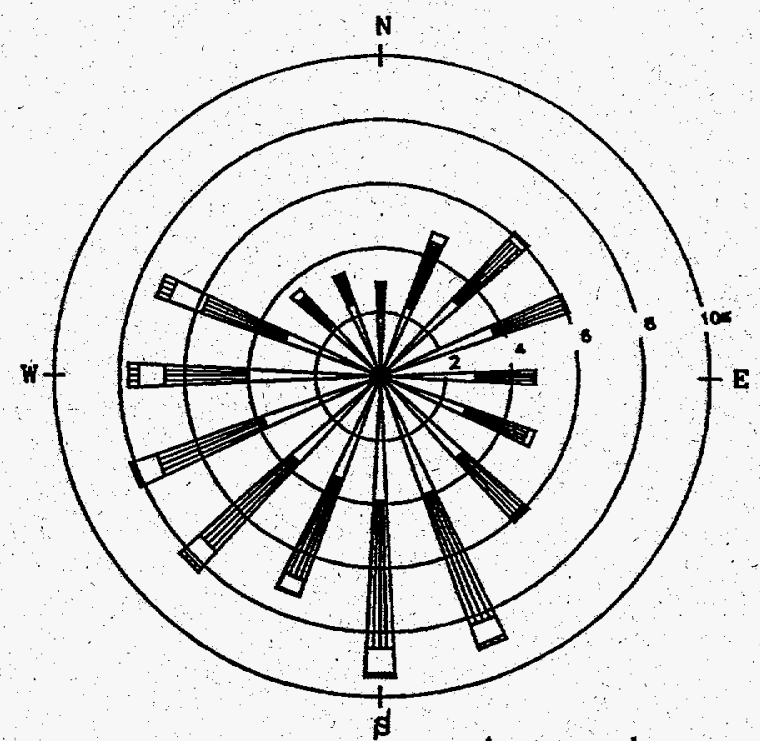

Avg. speed:

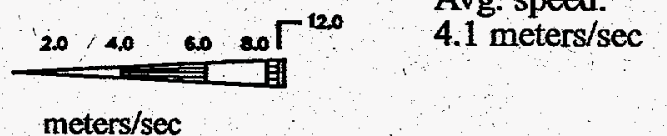

meters/sec

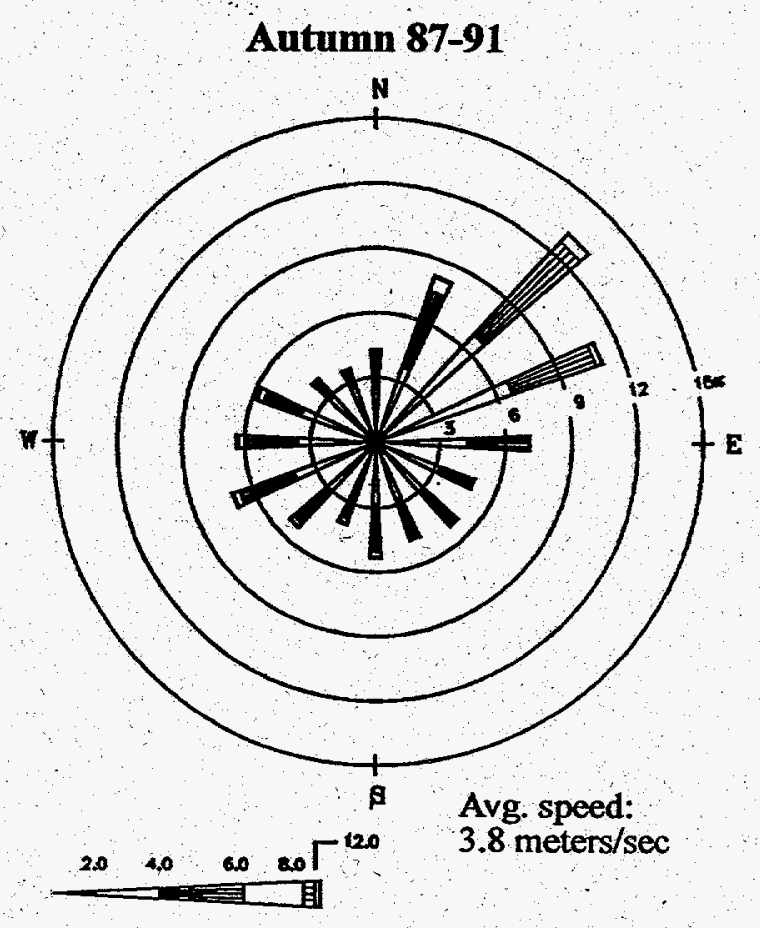

meters $/ \mathrm{sec}$

Figure 14. Seasonal wind rose 1987-91 (Note-Directions are compass sectors from which the wind is blowing:) 


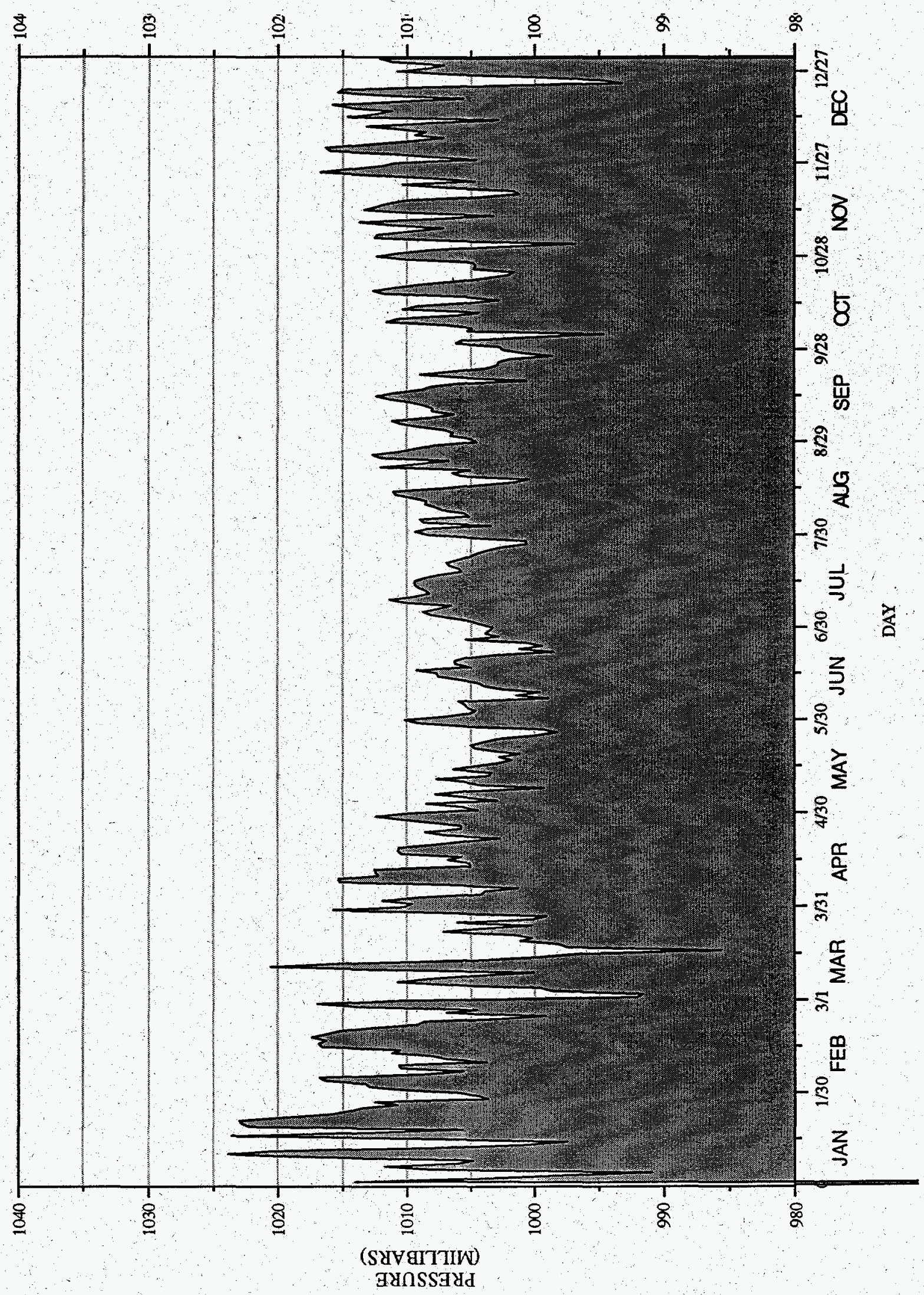




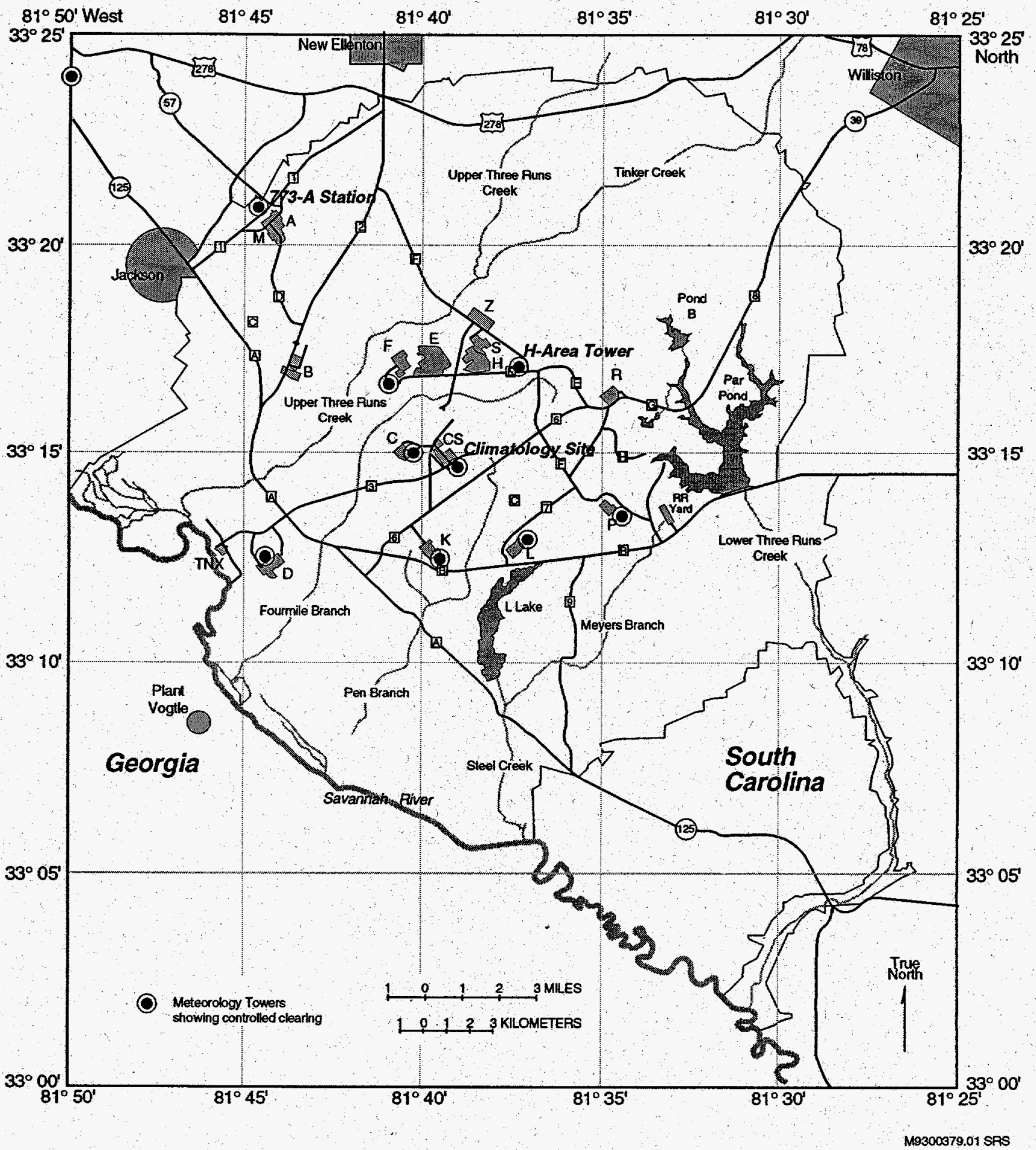

Attachment A. Map of the Savannah River Site showing the location of the meteorological towers. 


\section{"METEOROLOGICAL MONTHLY REPORT"" DISTRIBUTION}

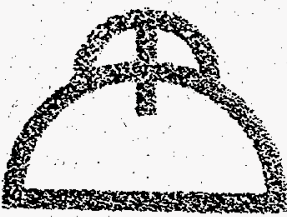

1. Jean Mobley (Librarian)
2. John Irwin
3. $\quad$ Amy Phillips
$4 . \quad$ A.W. Wiggins
$5 . \quad$ F.G. McNatt
$6 . \quad$ S. J Robertson
$7 . \quad$ R.M. Shulko
8. Rick Kowalski
$9 . \quad$ B.A. Beavers
$10 . \quad$ D.E. Stephenson
$11 . \quad$ C. W. Worley
$12 . \quad$ C.E. Jewell

SREL
USFS
ETS
Room 7
SRS
Rm. 282
CONST
Power Eng
E\&PD
SRS

\author{
$737-\mathrm{A}$ \\ $760-\mathrm{G}$ \\ $779-9 \mathrm{~A}$ \\ $24 \mathrm{I}-84 \mathrm{H}$ \\ $704-8 \mathrm{H}$ \\ $704-59 \mathrm{~F}$ \\ $773-41 \mathrm{~A}$ \\ $\mathrm{MDC}-112$ \\ 724-A \\ $992-4 W$ \\ $735-11 \mathrm{~A}$ \\ 704-P
}

13. U.S. Dept of Agriculture

1555 Richland Ave., East, Suite 600, Aiken, S.C. 29801

14. Charles Pair

15. Jamie Scout

Larry Bryan

USFS

SREL

17. S. C. State Climatology Office 1201 Main St., Suite 100, Columbia, S.C. 29201

18. Cliff Cole

19. G.L.Toole

20. Alice Stieve

21. Larty Eldridge

22. A. L. Baxley Jr.

23. Ralph L Nichols

24. Bob DeLisle

25. Brian Culligan

26. Marilynn Alfaro

27. T. C Sanders

28. Joe Pechmann

29. Kenneth Dixon

30. Tony Dunbar

31. Mark Smith

32. Jim Serafin

33. Stuart Stinson

34 Chuck Hunter

$\begin{array}{ll} & 773-43 \mathrm{~A} \\ \text { E\&PD } & 777-10 \mathrm{~A} \\ \text { ETD } & 992-4 \mathrm{~W}, \text { Cub } 111 \\ \text { Procurement } & 735-11 \mathrm{~A} \\ \text { SRTC } & 979-\mathrm{W}, \mathrm{Rm} 127 \\ \text { Corps of Engineers } & 773-42 \mathrm{~A} \\ \text { ALARA Env. Sup } & 740-6 \mathrm{~A} \\ \text { EMS } & 735-11 \mathrm{~A} \\ \text { Power } & 773-57 \mathrm{~A} \\ \text { SREL } & 724-\mathrm{A} \\ & 737-\mathrm{A} \\ \text { ER } & 773-42 \mathrm{~A} \\ \text { ERC } & 992-4 \mathrm{~W}, \mathrm{Rm} 321 \\ & 992-4 \mathrm{~W}-261 \\ \text { ETD } & 992-4 \mathrm{~W}, \mathrm{Cub} 37 \\ \text { ETS } & 735-11 \mathrm{~A} \\ & 773-\mathrm{A}, \mathrm{A}-1009 \\ \end{array}$

$704-56 \mathrm{H}$

$760-5 \mathrm{G}$

737-A
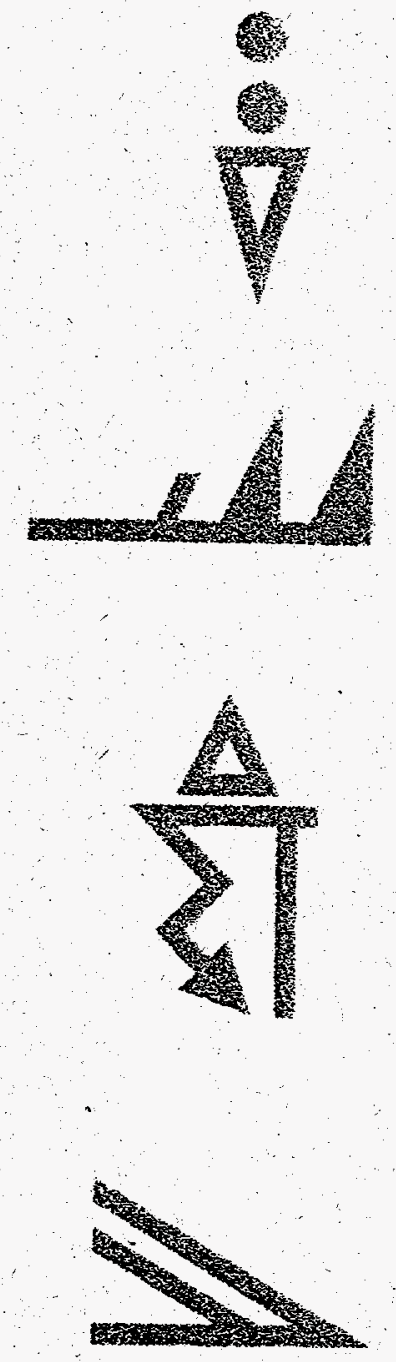

FROM: SRTC WEATHER CENTER-773-A. ROOM A-1002. (803) 725-1182

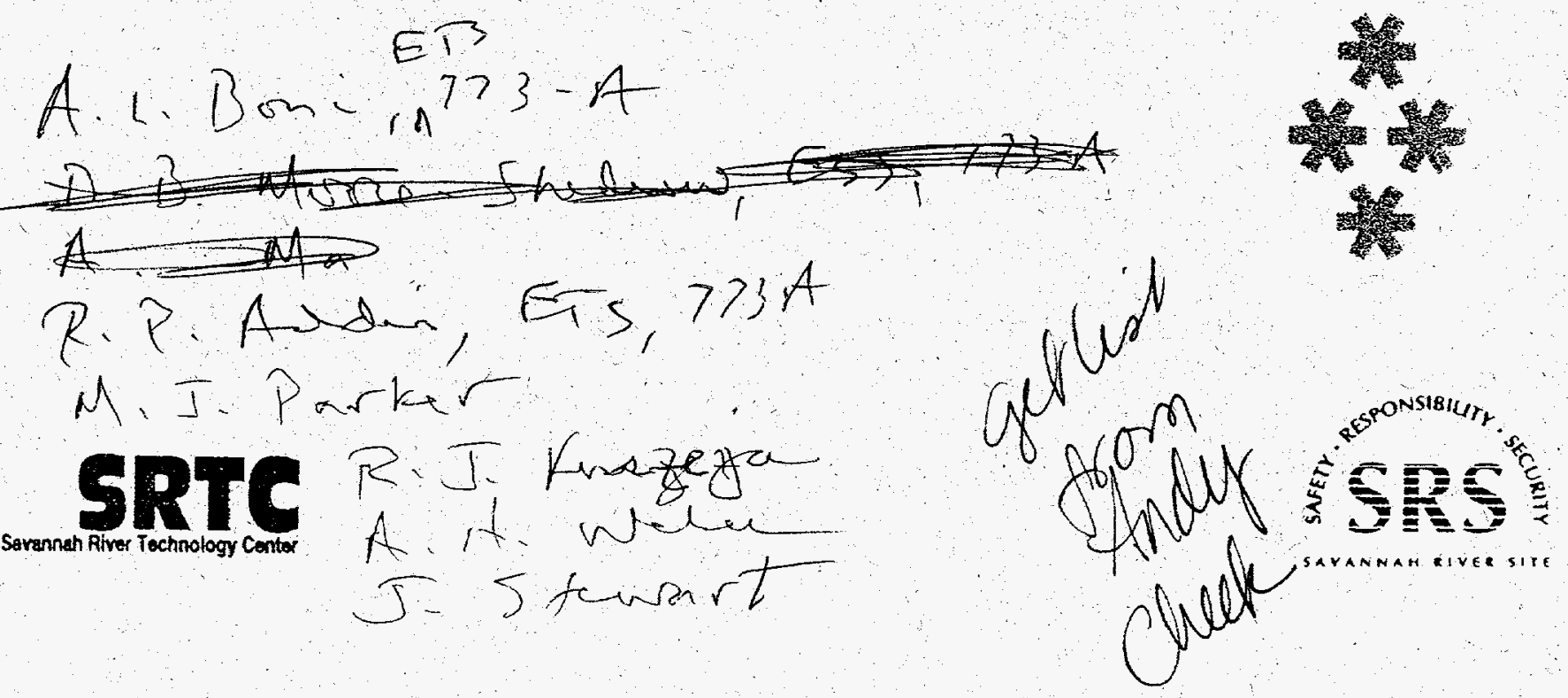

